\title{
Incentives for Sustainable National Greenhouse Gas Inventory in Developing Countries
}

\author{
Masato Kawanishi and Ryo Fujikura
}

\begin{abstract}
The present study aims to identify factors that differentiate developing countries in terms of their sustainable national greenhouse gas (GHG) inventories. To this end, we evaluated the inventory systems of 10 non-Annex I countries in Eastern Europe and Central Asia by scoring their submitted national communications against eight criteria. We find that the range of assigned scores widened with time among these countries due to the $\mathbf{E U}$ accession process, which has created a strong incentive for the countries concerned to establish sustainable national GHG inventory systems. This finding has implications for designing development assistance as part of a broader strategy to engage developing countries in climate actions, which should merit further elaboration.
\end{abstract}

Index Terms-Capacity building, climate change, development assistance, greenhouse gas inventory.

\section{INTRODUCTION}

A national greenhouse gas (GHG) inventory identifies and quantifies a country's anthropogenic sources and sinks of GHGs. It forms the foundation for accounting and tracking progress toward climate change mitigation goals [1]. However, many non-Annex I countries under the United Nations Framework Convention on Climate Change (UNFCCC) do not yet have the necessary capacity to produce regular inventories of their GHG emissions [2]-[5]. With more frequent reporting requirements under the UNFCCC, non-Annex I countries need to build capacity to support more sustainable and robust systems for national GHG inventory preparation. Establishing such systems enables countries to meet the reporting requirements; it also helps them identify and prioritize mitigation actions, and track and report progress toward domestic emissions reduction goals.

National GHG inventories of non-Annex I countries are reported to the secretariat of the UNFCCC through national communications (NCs) and biennial update reports (BURs). $\mathrm{NCs}$ provide information on national GHG inventories, as well as measures to mitigate and to facilitate adequate adaptation to climate change. BURs provide updates to the information contained in NCs, including GHG inventories [6]. Financial support is essential for developing countries for the preparation of their NCs and BURs; this is provided by the Global Environmental Facility (GEF) as an operational entity of the financial mechanism of the UNFCCC.

The Paris Agreement [7] established an enhanced

Manuscript received August 2, 2017; revised September 24, 2017.

M. Kawanishi is with Japan International Cooperation Agency, Tokyo, Japan (e-mail: Kawanishi.Masato@jica.go.jp).

R. Fujikura is with the Faculty of Sustainability Studies, Hosei University, Tokyo, Japan (e-mail: fujikura@hosei.ac.jp). transparency framework for action and support (Article 13.1), which will build on the existing transparency arrangements such as NCs and BURs (Article 13.4). One of the main purposes of the transparency framework is tracking progress toward achieving the Parties' individual nationally determined contributions (NDCs) (Article 13.5). In this respect, it is stipulated that each Party shall regularly provide a national inventory report (Article 13.7 (a)).

Our previous study [8] evaluated potential factors that enable developing countries to update national GHG inventories on a regular basis. By analyzing to what extent each factor differentiates frequency of submissions by countries of NCs and BURs to the UNFCCC, we found that funding support by the GEF has not made significant differences in terms of the frequency of updating inventories. Building on this previous study, the current paper examines the sustainability of the national GHG inventory systems in 10 non-Annex I countries: Albania, Armenia, Azerbaijan, Georgia, the Former Yugoslav Republic of Macedonia (referred to as "Macedonia" in this paper), Moldova, Mongolia, Tajikistan, Turkmenistan, and Uzbekistan. These countries participated in the regional project "Capacity Building for Improving the Quality of Greenhouse Gas Inventories in the Eastern Europe and Commonwealth of Independent States (CIS) region," implemented by the United Nations Development Programme (UNDP) with funding support by GEF for three years starting in 2003. This was one of two such regional projects, supported by UNDP and GEF, for GHG inventory capacity building. According to the project document [9], the countries had not been able to create sustainable institutional capacities for compiling, archiving, updating, and managing inventory data. This problem was addressed by the project with a common set of expected outputs and activities across the target countries. It was implemented during the time between the submissions of the initial and second NCs. Despite the common problem addressed and approach taken by the above project, the national GHG inventory systems have subsequently become more sustainable in some of these countries than in others. The present study examines factors that may explain this differentiation. The paper begins with the identification of a framework for evaluation and analysis. This is followed by presentation of the results and discussion of the implications of the findings for the design of development assistance.

\section{FRAMEWORK FOR EVALUATION AND ANALYSIS}

\section{A. Identification of Evaluation Criteria}

This paper used the findings from a 2013 synthesis of 
national inventory system practices and experiences [10] to identify eight evaluation criteria that were subsequently used with modifications to interrogate NCs from 10 non-Annex I countries. The evaluation criteria are: (1) sustained institutional arrangements, (2) a lead agency to manage the national GHG inventory process, (3) sectoral coordinating institutions, (4) institutional mandates and data-sharing agreements, (5) processes to archive inventory information, (6) external funding sources, (7) domestic funding sources, and (8) an iterative approach to improving the national inventory system.

\section{B. Scoring against Evaluation Criteria}

Given the limited number of BURs submitted by the target countries, this study focused on NCs as sources of information regarding the national GHG inventories. All the relevant NCs are available on the UNFCCC website [11]. Evaluation of all the submitted NCs was conducted by scoring each report against the aforementioned eight criteria with scoring adapted from a 2011 evaluation of climate adaptation plans [12]. Each criterion was scored on a three-point scale $(0,1$, or 2$)$, except the criterion "external funding sources," where a two-point scale ( 0 or 1$)$ was used for scoring. The pre-specified requirements associated with each possible score are presented in Table I.

\section{Analysis of Differentiating Factors}

Per capita GDP and $\mathrm{CO}_{2}$ emissions were evaluated for their potential to differentiate countries in terms of the sustainability of their national GHG inventories. This was based on the hypotheses that (1) countries with larger GDP per capita are more likely to have internal funding sources to sustain a national GHG inventory, and (2) the countries with higher GHG emissions per capita are more likely to have incentives to quantify their sources and sinks of GHGs. To this end, we calculated the correlation coefficients between the most current data on two variables - per capita GDP and $\mathrm{CO}_{2}$ emissions [13] - and the total scores on national GHG inventory assigned to the most recent NCs of the respective target countries. In addition, we examined the relationships between sustainable national GHG inventory and types of climate change mitigation goal, such as coverage of different gases and sectors, as documented in the respective countries' NDCs [14]. Other potential factors, such as the accession to the European Union (EU), were also explored through desk-top reviews of the submitted NCs and other relevant documents.

\section{Limitations}

The evaluation approach used here assessed only information contained within the NCs. Although non-Annex I countries are mandated to report national GHG inventories, the guidelines for their NCs indicate that they are only "encouraged to describe procedures and arrangements undertaken to collect and archive data for the preparation of national GHG inventories, as well as efforts to make this a continuous process, including information on the role of the institutions involved" [15]. It is important to recognize that, even if not reported, significant investments of time and resources in developing the above procedures and arrangements may have occurred behind the scenes. It is also possible that national GHG inventory systems may not actually function as reported.

TABLE I: SCORING RULES FOR EVALUATION OF NATIONAL REPORTS AGAINST CRITERIA

\begin{tabular}{|c|c|c|}
\hline Criterion & $\begin{array}{l}\text { Score of " } 1 \text { " requires } \\
\text { evidence that ... }\end{array}$ & $\begin{array}{c}\text { Score of " } 2 \text { " requires } \\
\text { evidence that ... }\end{array}$ \\
\hline $\begin{array}{l}\text { Sustained } \\
\text { institutional } \\
\text { arrangements }\end{array}$ & $\begin{array}{l}\text { Relevant organizations } \\
\text { have been designated. }\end{array}$ & $\begin{array}{l}\text { Relevant organizations } \\
\text { have been designated, } \\
\text { and processes for } \\
\text { interaction among } \\
\text { these organizations } \\
\text { have been defined. }\end{array}$ \\
\hline $\begin{array}{l}\text { A lead agency to } \\
\text { manage the } \\
\text { national GHG } \\
\text { inventory } \\
\text { process }\end{array}$ & $\begin{array}{l}\text { An overall lead agency has } \\
\text { been designated. }\end{array}$ & $\begin{array}{l}\text { An overall lead agency } \\
\text { has been designated, } \\
\text { and its roles and } \\
\text { responsibilities have } \\
\text { been defined. }\end{array}$ \\
\hline $\begin{array}{l}\text { Sectoral } \\
\text { coordinating } \\
\text { institutions }\end{array}$ & $\begin{array}{l}\text { Sectoral coordinating } \\
\text { institutions have been } \\
\text { designated. }\end{array}$ & $\begin{array}{l}\text { Sectoral coordinating } \\
\text { institutions have been } \\
\text { designated, and their } \\
\text { roles and } \\
\text { responsibilities have } \\
\text { been defined. }\end{array}$ \\
\hline $\begin{array}{l}\text { Institutional } \\
\text { mandates and } \\
\text { data-sharing } \\
\text { agreements }\end{array}$ & $\begin{array}{l}\text { The necessity of } \\
\text { establishing institutional } \\
\text { mandates and } \\
\text { data-sharing agreements } \\
\text { has been recognized, or } \\
\text { there is a plan to address } \\
\text { this issue. }\end{array}$ & $\begin{array}{l}\text { Institutional mandates } \\
\text { and data-sharing } \\
\text { agreements have been } \\
\text { established. }\end{array}$ \\
\hline $\begin{array}{l}\text { Processes to } \\
\text { archive } \\
\text { inventory } \\
\text { information }\end{array}$ & $\begin{array}{l}\text { The necessity of } \\
\text { developing processes to } \\
\text { archive inventory } \\
\text { information has been } \\
\text { recognized, or such there } \\
\text { is a plan to develop such } \\
\text { processes. }\end{array}$ & $\begin{array}{l}\text { Processes to archive } \\
\text { inventory information } \\
\text { have been established. }\end{array}$ \\
\hline External funding & $\begin{array}{l}\text { GEF funds and other } \\
\text { international financial } \\
\text { resources have been } \\
\text { secured to develop a } \\
\text { national GHG inventory. }\end{array}$ & N/A \\
\hline Domestic funding & $\begin{array}{l}\text { The necessity of securing } \\
\text { funding through national } \\
\text { budgets and/or other } \\
\text { domestic sources to } \\
\text { sustain a national GHG } \\
\text { inventory system has } \\
\text { been recognized. }\end{array}$ & $\begin{array}{l}\text { Funds from national } \\
\text { budgets and/or other } \\
\text { domestic sources have } \\
\text { been secured to sustain } \\
\text { a national GHG } \\
\text { inventory system. }\end{array}$ \\
\hline $\begin{array}{l}\text { An iterative } \\
\text { approach to } \\
\text { improving the } \\
\text { national } \\
\text { inventory } \\
\text { system }\end{array}$ & $\begin{array}{l}\text { Gaps and constraints in a } \\
\text { national GHG inventory } \\
\text { have been recognized. }\end{array}$ & $\begin{array}{l}\text { The improvement plan } \\
\text { for a national GHG } \\
\text { inventory has been } \\
\text { continuously updated. }\end{array}$ \\
\hline
\end{tabular}

\section{RESULTS}

As shown in Table II, the years in which NCs were submitted are from 1998 to 2003 for NC1, from 2008 to 2010 for NC2, and from 2014 to 2017 for NC3; the UNDP/GEF regional project was implemented in the interval between the submissions of NC1 and NC2. Figure 1 depicts the changes in total scores for sustainable national GHG inventory in the 10 target countries through time, based on the information provided in their submitted NCs. The range in the assigned scores across the countries widened with time: the scores ranged between 1 and 4 for $\mathrm{NC} 1$, and between 5 and 14 for NC3. The latest scores for Albania, Macedonia, and Moldova are much higher than those for the remaining countries. The UNDP/GEF regional project helped the participating 
countries in enhancing technical capacities for preparation of GHG inventories: notable improvements in methods for estimating emissions and factors were reported to have taken place. For example, Armenia developed a composite model of municipal solid waste to improve the emission factor; Tajikistan carried out landfill gas measurements to better estimate the fraction of methane in their landfill gas; and Uzbekistan also improved emission factors and activity data for fugitive methane emissions from oil and gas operations [16]. Despite such technical progress, the improvements in their sustainable national GHG inventory system scores have been limited, as shown in Fig. 1.

Potential factors that differentiate countries in terms of sustainable national GHG inventory were examined. The correlations of the assigned scores for national GHG inventory with per capita GDP and $\mathrm{CO}_{2}$ emissions are presented in Table III. As indicated by the $p$-values exceeding the significance level of 0.05 , the correlations are not statistically significant.

TABLE II: YEARS OF SUBMISSIONS OF NATIONAL COMMUNICATIONS (NCS) AND BIENNIAL UPDATE REPORTS (BURS) UNDER THE UNITED NATIONS

\begin{tabular}{lllll}
\multicolumn{5}{c}{ FRAMEWORK CONVENTION ON CLIMATE CHANGE } \\
\hline Albania & NC1 & NC2 & NC3 & BUR1 \\
\hline Armenia & 2002 & 2009 & 2016 & - \\
\hline Azerbaijan & 1998 & 2010 & 2016 & - \\
\hline Georgia & 2000 & 2010 & 2015 & - \\
\hline Macedonia & 1999 & 2009 & 2016 & - \\
\hline Moldova & 2003 & 2009 & 2014 & 2015 \\
\hline Mongolia & 2000 & 2010 & 2014 & 2016 \\
\hline Tajikistan & 2001 & 2010 & - & - \\
\hline Turkmenistan & 2002 & 2008 & 2014 & - \\
\hline Uzbekistan & 2000 & 2010 & 2016 & - \\
\hline Note: (-)indicate “not & 1999 & 2008 & 2017 & - \\
\hline
\end{tabular}

Note: (-) indicates "not yet submitted as of July 2017." The Former Yugoslav Republic of Macedonia is referred to as "Macedonia" in the table.

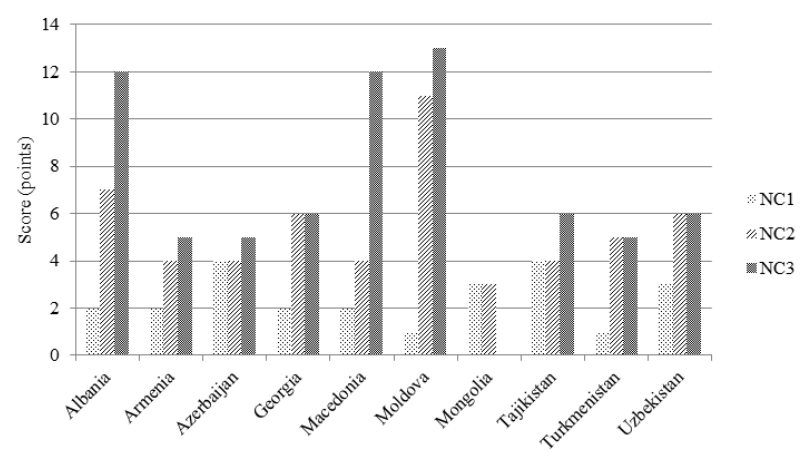

Fig. 1. National GHG inventory system scores as based on documentation in the national communications (NCs) submitted under the United Nations Framework Convention on Climate Change. (The Former Yugoslav Republic of Macedonia is referred to as "Macedonia" in the figure.)

Table IV presents a summary of climate change mitigation contributions as documented in the NDCs submitted by the target countries. It shows that these countries have communicated a diverse range of contributions. On one hand, these include different forms of GHG goals: relative to a base year for Azerbaijan, Moldova, and Tajikistan; relative to a baseline for Albania; and a fixed level goal for Armenia. On the other hand, Mongolia and Turkmenistan expressed their commitments in non-GHG terms such as implementation of policies and measures, even though they estimated the GHG effects of these contributions. Coverages of different gases and sectors, as well as conditions attached to the contributions also vary. The table does not indicate any clear relationship between the level of sustainability of national GHG inventory systems and the type of mitigation goals that have been chosen by the countries. It is not necessarily the case that countries with sustainable GHG inventory systems are more likely to have set mitigation goals relative to a base year and covering all sectors and gases, as Annex I countries do. It is not necessarily the case either that countries with such mitigation goals are more likely to have established sustainable GHG inventory systems.

TABLE III: CORRELATIONS OF GHG INVENTORY SCORES WITH PER CAPITA GDP AND $\mathrm{CO}_{2}$ EMISSIONS

\begin{tabular}{lll}
\hline & $\begin{array}{c}\text { Between scores from } \\
\mathrm{NC3} * \text { and per capita } \\
\text { GDP ** }\end{array}$ & $\begin{array}{l}\text { Between scores from } \mathrm{NC} 3 * \\
\text { and per capita } \mathrm{CO}_{2} \\
\text { emissions *** }\end{array}$ \\
\hline $\begin{array}{c}\text { Correlation } \\
\text { coefficient }\end{array}$ & -0.2026 & -0.4837 \\
\hline$p$ value & {$[0.5757 * * * *]$} & {$[0.1573 * * * *]$}
\end{tabular}

Notes: * National GHG inventory system scores as based on documentation in the national communications (NCs) submitted under the United Nations Framework Convention on Climate Change (Score of NC2 in case of Mongolia, which has not submitted NC3 as of July 2017); ** data as of 2015; $* * *$ data as of 2013 ; **** not significant at 0.05 level.

Further desk-top reviews of the NCs and other relevant documents reveal that the EU accession process has created strong incentives for the countries concerned to establish sustainable national GHG inventory systems. What is common to the three highest scoring countries is that they have signed the Association Agreement with the EU, which serves as a basis for implementing the EU accession process. In particular, Albania and Macedonia have been granted EU candidate country status since 2014 and 2005, respectively: they are in the process of regulatory alignment with the EU. Albania's NC3 states that "the obligations under the UNFCCC and the EU integration process are the most important incentives to keep the country's intention to improve the inventory process" [17]. Macedonia reports that one of the "priorities for transposition" is the development of a rule and procedures for the preparation of their national GHG inventory [18]. It also reports on the participation of the national GHG inventory team in "the preparation of a Roadmap for the introduction of a Monitoring, Reporting and Verification system under the EU Emissions Trading Scheme" [19].

Among the EU laws the Member States have to adopt, the "Regulation (EU) No 525/2013 of the European Parliament and of the Council of 21 May 2013 on a mechanism for monitoring and reporting greenhouse gas emissions and for reporting other information at national and Union level relevant to climate change and repealing Decision No 280/2004/EC (1)" is most relevant to the topic of this study [20]. It stipulates that "Member States shall establish, operate and seek to continuously improve national inventory systems" (Article 5) and "shall determine and report" their inventories to the European Commission each year (Article 7). It also stipulates that "Member States ... shall prepare their low-carbon development strategies" and report on the status of implementation (Article 4).

Although they have not been granted EU candidate country status, Moldova and Georgia are two other countries that have signed the Association Agreements. Moldova's 
NC3 states that a low emission development strategy, including "provisions on monitoring, reporting and verification," has been formulated at the national level in accordance with the Association Agreement [21]. On the other hand, Georgia's NC3 states that, with regard to institutional strengthening on GHG inventory, "unfortunately at this point this is not done at [the] national level, but is taking place at the level of towns," and these local initiatives are supported by the EU and other donors [22]. The differing of the national GHG inventory scores between these two countries may arise from the above-mentioned difference in focus at this stage, that is, on either a national- or local-level.

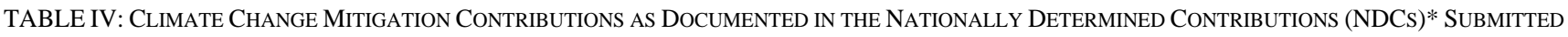
UNDER THE UNITED NATIONS FRAMEWORK CONVENTION ON CLIMATE CHANGE

\begin{tabular}{|c|c|c|c|c|c|c|c|}
\hline Albania & Armenia & Azerbaijan & Georgia & Moldova & Mongolia & Tajikistan & Turkmenistan \\
\hline \multicolumn{8}{|c|}{$\begin{array}{l}\text { Commitment type: (A) GHG emissions reductions, relative to a base year; (B) GHG emissions reductions, relative to a BAU baseline; (C) absolute emissio } \\
\text { limitation target; (D) commitments expressed in terms of non-GHG metrics, such as implementation of policies and measures. }\end{array}$} \\
\hline B (11.5\%) & $\mathrm{C} * *$ & A $(35 \%)$ & B (15\%) & A $(64-67 \%)$ & $\mathrm{D} * * *$ & $\mathrm{~A}(10-20 \%)$ & $\mathrm{D} * * *$ \\
\hline \multicolumn{8}{|l|}{ Time frame: } \\
\hline 2016-30 & 2050 & 2030 & 2030 & 2030 & up to 2030 & $2021-30$ & up to 2030 \\
\hline \multicolumn{8}{|l|}{ Base year: } \\
\hline N/A & N/A & 1990 & N/A & 1990 & N/A & 1990 & N/A \\
\hline \multicolumn{8}{|c|}{ Coverage of gases: } \\
\hline $\mathrm{CO}_{2}$ only & Selected gases & Selected gases & All gases & All gases & N/A & Selected gases & N/A \\
\hline \multicolumn{8}{|c|}{ Coverage of sectors: } \\
\hline $\begin{array}{l}\text { Selected } \\
\text { sectors }\end{array}$ & Economy wide & Economy wide & $\begin{array}{l}\text { Selected } \\
\text { sectors }\end{array}$ & Economy wide & N/A & Selected sectors & N/A \\
\hline \multicolumn{8}{|c|}{ Conditions: (A) Commitments are to be unconditional; (B) conditions may be attached to commitments. } \\
\hline A & A & A & $\mathrm{A} * * * *$ & A $* * * *$ & $\mathrm{~B}$ & $\mathrm{~A} * * * *$ & A \\
\hline
\end{tabular}

\section{DISCUSSION}

A national GHG inventory is a foundation for accounting and tracking progress toward climate change mitigation goals However, unlike the cases of technology transfer or finance, it does not bring about immediate and material benefits. Some developing countries may therefore be reluctant to use their limited domestic resources to establish sustainable national GHG inventory systems. This paper presents the case that a national GHG inventory has become sustainable in some countries in the process of their regulatory alignment with the EU, where the greatest incentive is the future prospect of EU candidacy and ultimately admission into the EU. In relation to this, Victor [23] discussed the necessity of creating stronger incentives to engage "reluctant" countries in what he called the "Climate Accession Deals." He argued that incentives should be tailored to the particular interests of the concerned countries. The potential benefits could include linkage with carbon markets, direct support for transfers of low-carbon technologies, and access to funds for climate change mitigation and adaptation projects. He recognized that, to some extent, these kinds of practices have already been established through the process of bilateral and multilateral development assistance.

One such example is the Climate Change Program Loan (CCPL) provided to the Government of Indonesia by Japan International Cooperation Agency (JICA) and Agence Francais de Developpement (AFD) between 2008 and 2010, and joined by the World Bank in 2010. Under the CCPL, the funds were channeled into the state budget, but released on a yearly basis pending performance checks on the agreed-upon steps in the implementation of climate change policies by the country. The agreed-upon steps and related indicators were summarized in a policy matrix, which was the main tool for monitoring. One of the three main outcome targets placed on the matrix was a "monitoring mechanism for carbon emissions and absorption established through a national GHG inventory system." According to the AFD/JICA joint evaluation report [24], the progress in this area includes establishment of a GHG inventory system unit in 2010, issuance of the Presidential Regulation on the national GHG inventory in 2011, and completion of the general inventory guidelines in 2011. The reported progress is shown in Figure 2 , which illustrates the changes in the sustainable national GHG inventory scores as assigned using the scoring rule defined in Table I, based on the information provided in three national reports submitted by Indonesia: NC1 in 1999, NC2 in 2011, and BUR1 in 2016.

An assessment by the World Bank [25] also identified "a considerable potential value [in CCPL] as a convening instrument" for the engagement strategy with respect to climate change policy reform. As a way of designing development assistance as part of a broader strategy to engage developing countries in climate actions, "Climate Accession Deals" [23] merit further elaboration.

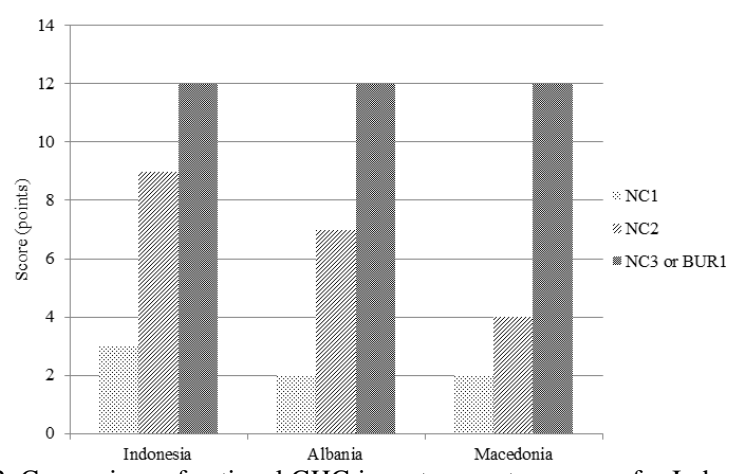

Fig. 2. Comparison of national GHG inventory system scores for Indonesia, Albania, and the Former Yugoslav Republic of Macedonia (referred to as "Macedonia" in the figure), as determined from national communications (NCs) and biennial update reports (BURs) submitted under the United Nations Framework Convention on Climate Change. 


\section{ACKNOWLEDGMENT}

The opinions expressed in this paper are those of the authors and do not necessarily represent the views of the organizations to which the authors belong.

\section{REFERENCES}

[1] C. Hood, G. Briner, and M. Rocha, GHG or Not GHG: Accounting for Diverse Mitigation Contributions in the Post-2020 Climate Framework, Paris: OECD/IEA, 2014.

[2] A. Herold, Current Status of National Inventory Preparation in Annex I Parties and Non-Annex I Parties, Paris: OECD/IEA, 2003.

[3] S. Willems and K. Baumert, Institutional Capacity and Climate Actions, Paris: OECD/IEA, 2003.

[4] C. Breidenich, Improving Reporting of National Communications and GHG Inventories by Non-Annex I Parties under the Climate Convention, New York, NY: Natural Resources Defence Council, 2011.

[5] J. Ellis and S. Moarif, Identifying and Addressing Gaps in the UNFCCC Reporting Framework, Paris: OECD/IEA, 2015.

[6] UNFCCC. (2010). Report of the Conference of the Parties on Its Sixteenth Session, Held in Cancun from 29 November to 10 December $2010 . \quad$ [Online]. Available: http://unfccc.int/resource/docs/2010/cop16/eng/07a01.pdf\#page=2

[7] UNFCCC. (2015). Report of the Conference of the Parties on Its Twenty-First Session, Held in Paris from 30 November to 13 December 2015. [Online]. Available: http://unfccc.int/resource/docs/2015/cop21/eng/10a01.pdf\#page=2

[8] M. Kawanishi and R. Fujikura, "Evaluation of enabling factors for sustainable national greenhouse gas inventory in developing countries".

[9] UNDP/GEF. (2001). Project Brief: Capacity Building for Improving the Quality of Greenhouse Gas Inventories (Europe/CIS Region). [Online]. Available: https://www.thegef.org/sites/default/files/project_documents/Regional _Capacity_Building_for_Improving_the_Quality_of_GHG.pdf

[10] T. Damassa and S. Elsayed, From the GHG Measurement Frontline: A Synthesis of Non-Annex I Country National Inventory System Practices and Experiences, Washington, DC: World Resource Institute, 2013.

[11] UNFCCC. (2017). National Reports. [Online]. Available: http://unfccc.int/national_reports/items/1408.php

[12] B. L. Preston, R. M. Westaway, and E. J. Yuen, "Climate adaptation planning in practice: an evaluation of adaptation plans from three developed nations," Mitig. Adapt. Strategies. Glob. Chang., vol. 16, no. 4, pp. 407-438., 2011.

[13] World Bank. (2017). Word Development Indicator. [Online]. Available: http://data.worldbank.org/indicator

[14] UNFCCC. (2017). Interim NDC Registry. [Online]. Available: http://www4.unfccc.int/ndcregistry/Pages/Home.aspx

[15] UNFCCC. (2002). Report of the Conference of the Parties on its Eighth Session, Held in New Delhi from 23 October to 1 November 2002. [Online]. http://unfccc.int/resource/docs/cop8/07a02.pdf\#page=2

[16] Regional Environmental Center for Central and Eastern Europe, Improving National Greenhouse Gas Inventories: Success Stories from Europe and the CIS Region, Szentendre, Hungary: REC, 2005.

[17] Ministry of Environment, Albania. (2016). Third National Communication of the Republic of Albania under the United Nations Framework Convention on Climate Change. [Online]. Available: http://unfccc.int/files/national_reports/non-annex_i_natcom/applicatio n/zip/albania_nc3_13_october_2016.zip
[18] Ministry of Environment and Physical Planning, Macedonia. (2008). National Strategy of Environmental Approximation. [Online] Available:

http://www.moepp.gov.mk/wp-content/uploads/2014/12/National-Stra tegy-for-Environmental-Approximation1.pdf

[19] Ministry of Environment and Physical Planning, Macedonia. (2013). Preparation of the GHG inventory for the Third National Communication to the UNFCCC. [Online]. Available: http://unfccc.int/files/national_reports/non-annex_i_parties/applicatio n/zip/nir_tnc_macedonia.zip

[20] EU, "Regulation (EU) No 525/2013 of the European Parliament and of the Council of 21 May 2013 on a mechanism for monitoring and reporting greenhouse gas emissions and for reporting other information at national and Union level relevant to climate change and repealing Decision No 280/2004/EC(1)," Official Journal of the European Union, vol. L165/1, 2013.

[21] Ministry of Environment, Moldova. (2013). Third National Communication of the Republic of Moldova under the United Nations Framework Convention on Climate Change. [Online]. Available: http://unfccc.int/resource/docs/natc/mdanc3.pdf

[22] Ministry of Environment and Natural Resource Protection, Georgia. (2015). Georgia's Third National Communication to the UNFCCC. [Online]. Available: http://unfccc.int/resource/docs/natc/geonc3.pdf

[23] D. G. Victor, Climate Accession Deals: New Strategies for Taming Growth of Greenhouse Gases in Developing Countries, Cambridge, MA: The Harvard Project on International Climate Agreements, 2008.

[24] AFD/JICA. (2014). Joint Evaluation: Indonesia Climate Change Programme Loan. [Online]. Available: https://www2.jica.go.jp/en/evaluation/pdf/2013_INP-33_4.pdf

[25] World Bank. (2016). Project Performance Assessment Report: Indonesia Climate Change Development Policy Loan. [Online] Available:

https://ieg.worldbankgroup.org/Data/reports/PPAR_Indonesia.Clmt_. ChgDPL.pdf

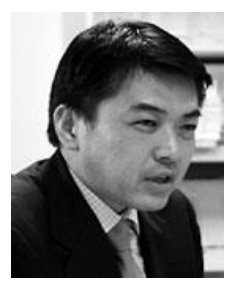

Masato Kawanishi obtained a doctor of engineering from Ibaraki University, Japan in 2014, a master of science from Imperial College London, UK in 2004, and a master of business administration from Boston University, USA in 1993.

$\mathrm{He}$ is senior advisor on climate change for Japan International Cooperation Agency (JICA), Tokyo, Japan.

Dr. Kawanishi co-edited with Prof. Ryo Fujikura "Climate change adaptation and international development: Making development cooperation more effective" (London, UK: Earthscan, 2010), and with Prof. Shinji Kaneko "Climate change policies and challenges in Indonesia" (Tokyo, Japan: Springer, 2016).

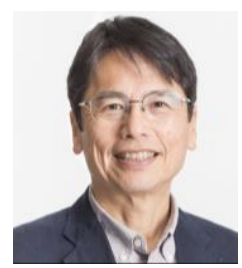

Ryo Fujikura obtained a doctor of natural science from Innsbruck University, Austria in 1982, and a master of science from the University of Tokyo in 1980 .

He is professor of Faculty of Sustainability Studies, Hosei University, Tokyo, Japan.

Prof. Fujikura co-edited with Dr. Tomoyo Toyota "Climate change mitigation and international development cooperation" (London, UK: Earthscan, 2012), and with Prof. Mikiyasu Nakayama "Resettlement policy in large development projects" (Oxford, UK: Routledge, 2015). 